\title{
Influence of Using Various Sugarcane Leaves and Parts of the Sugarcane Leaf on Chemical Composition
}

\author{
George Samuels ${ }^{1}$
}

\section{INTRODUCTION}

The taking of the sugareane-leaf sample can be the weakest link in the chain of procedure in foliar diagnosis. For, no matter how accurate the chemical analysis, an accurate diagnosis of the sugarcane's fertilizer status is impossible if leaf samples are taken improperly and this, in turn, limits the value of the fertilizer recommendation based on the subsequent analysis. Therefore, the taking of the leaf sample cannot be regarded as a mere routine; it requires careful and thoughtful procedure.

The sugarcane leaf is the vital area where the photosynthetic activity of the plant takes place. The content of nutrient elements in the leaf serves as a guide in evaluating the potential of the sugarcane plant to produce sugar tonnage. However, the sugarcane leaves of the plant are not homogeneous, and variations are encountered in various leaves, as well as within different parts of a given leaf. The data given here, collected from experiments of the Agronomy Department of the Agricultural Experiment Station, are presented to aid the agronomist and chemist in evaluating his procedures and results.

\section{METHODS}

The experiment for comparison of the various leaf numbers utilized 30 plants taken at random from a 4-month-old plant cane of P. R. 980 at Río Piedras. The experiment comparing the different parts of the sugarcane leaf made use of 25 plants taken at random from a 4-month-old plant cane of M.336 at Río Piedras. Leaves Nos. 3, 4, 5, and 6 were used from each plant. The nutrient variation along the leaf blade utilized leaves Nos. $3,4,5$, and 6 from 20 plants each of P.R. 980 from 3 replications of a variety experiment at Solis Farm, Río Piedras. The leaves were doubled to locate the center. The leaf was cut into 6 -inch sections starting from the center. The 6-inch sections were then divided into lamina and midrib. Corresponding samples were taken in the same manner, but the midrib was not removed. This set of samples was designated as "whole leaf".

Sugarcane leaves were dried in a forced-draft oven at $80^{\circ} \mathrm{C}$. for 24 hours, then ground to 60-mesh in a Wiley mill. Analyses for nitrogen, phosphorus,

${ }^{1}$ Agronomist, Agronomy and Horticulture Department, Agricultural Experiment Station, University of Puerto Rico, Río Piedras, P.R. 
and potassium were made by the Central Analytical Laboratory using standard chemical analysis methods of the Station (3). ${ }^{2}$

\section{LEAF NUMBER}

Although most practitioners of foliar diagnosis agree that young green leaves are the best portion of the sugarcane plant to use in sampling, the number of leaves used varies. The leaves selected vary from one to four, with or without midribs, and at times include the sheath.

First of all, the numbering of the sugarcane leaves and sheaths must be clarified. Such vague indications as, "The first leaf from the top", etc., have caused some confusion. Van Dillewijn (6, p. 103), one of the leading authori-

TABLE 1.-A comparison of the nutrient composition and moisture content of the different sugarcane leaves used for foliar diagnosis

\begin{tabular}{|c|c|c|c|c|c|c|c|}
\hline \multirow{3}{*}{ Leaf No. } & \multicolumn{7}{|c|}{ Nutrient content of the leaf, ${ }^{1}$ percent-dry-weight basis } \\
\hline & \multicolumn{3}{|c|}{ Leaf blade } & \multicolumn{4}{|c|}{ Leaf sheath } \\
\hline & Nitrogen & $\begin{array}{l}\text { Phos- } \\
\text { phorus }\end{array}$ & Potassium & Nitrogen & $\begin{array}{l}\text { Phos- } \\
\text { phorus }\end{array}$ & Potassium & Moisture \\
\hline 3 & 1.74 & 0.15 & 1.59 & .60 & 0.10 & 2.80 & 86.8 \\
\hline 4 & 1.80 & .14 & 1.43 & .62 & .07 & 2.20 & 82.9 \\
\hline 5 & 1.89 & .14 & 1.29 & .66 & .07 & 1.97 & 81.3 \\
\hline 6 & 1.84 & .12 & 1.13 & .63 & .06 & 1.79 & 79.9 \\
\hline Average & 1.82 & .14 & 1.36 & .63 & .08 & 2.19 & 82.7 \\
\hline
\end{tabular}

${ }_{1}^{1}$ The whole leaf including the midrib for P.R. 980.

ties on sugarcane morphology, favored the system of Kuijper for designating the various organs of the plant. Basically the system designates the highest visible dewlap as +1 , the leaf to which this dewlap belongs as leaf +1 , and the sheath and joint on which the leaf is implanted the same. Unfortunately, no such standard system is used throughout the world where sugarcane is grown. For the most part, the spindle leaf, when open to partly open, is designated as leaf No. 1, and the leaves are counted downward as $2,3,4$, ete.

A comparison of the various cane-leaf values is given in table 1 . There we can see that the leaf blade runs higher in nitrogen and phosphorus than does the leaf sheath. The ratio of nitrogen for leaf blade to sheath is about $3: 1$, and is one reason why the leaf blade is favored for nitrogen analysis. The phosphorus content of the leaf blade is about twice that of the sheath.

${ }^{2}$ Italic numbers in parentheses refer to Literature Cited, p. 28. 
For potassium the reverse holds true with the leaf sheath being much higher than the leaf blade.

Considering the leaf number, nitrogen shows little variation in the range of leaves normally sampled, with the tendency for the nitrogen content of the leaf to increase as the leaf number becomes higher. There is a general decrease in leaf phosphorus with increasing leaf number. The same holds true for leaf potassium and sheath moisture. The drop in values percentagewise from leaf No. 3 as compared with leaf No. 6 is more marked for sheath phosphorus and potassium than for the leaf blade.

\section{PART OF THE LEAF}

In very few cases is the entire cane leaf taken at sampling used for chemical analyses. To save space and time in drying the leaf material and in grinding, only a portion of the cane leaf is used.

TABLE 2.-A comparison of the nutrient composition of different parts of the sugarcane leaf blade, M.s36

\begin{tabular}{l|c|c|c}
\hline \multirow{2}{*}{ Part of blade } & \multicolumn{3}{|c}{ Nutrient content of sample on a percent-dry-weight basis for- } \\
\cline { 2 - 4 } & Nitrogen & Phosphorus & Potassium \\
\hline Whole & 1.62 & 0.15 & 1.53 \\
Lamina & 2.09 & .19 & 1.47 \\
Midrib & .79 & .09 & 2.12 \\
\hline
\end{tabular}

In all known methods of leaf sampling, with the exception of the Puerto Rican method $(4,5)$, the midrib is normally eliminated and only the lamina of the leaf is used. The elimination of the midrib requires extra work unless a leaf-punch technique is used. The midrib and the lamina of the leaf vary greatly in their nutrient contents (see table 2). Where the midrib is eliminated, leaf-nitrogen and -phosphorus values are higher, but leaf potassium is lower than where the whole leaf is utilized. The reason for this variation, resulting from the exclusion of the midrib from the sample, is that the midrib itself is lower in nitrogen and phosphorus and higher in potassium than the corresponding lamina. Halais (2) found in Mauritius a quite similar relationship between leaf-blade lamina and midrib.

Usually some portion of the center of the cane leaf is taken for preparing the leaf sample. Those countries using the whole leaf reduce the bulk of the sample by taking 6-inch sections from the basal, center, and terminal portion of the leaf, including the midrib. For the most part, the location of the center of the long axis of the leaf is estimated by eye, and there is considerable variation by different operators. There is a marked tendency to choose the center of the area rather than the true center of length. It has 
been found that the point selected by eye can be as much as 12 inches towards the basal portion from true center of length; and, moreover, the center chosen by eye by different operators was found to vary as much as 5 inches on the one sample (1).

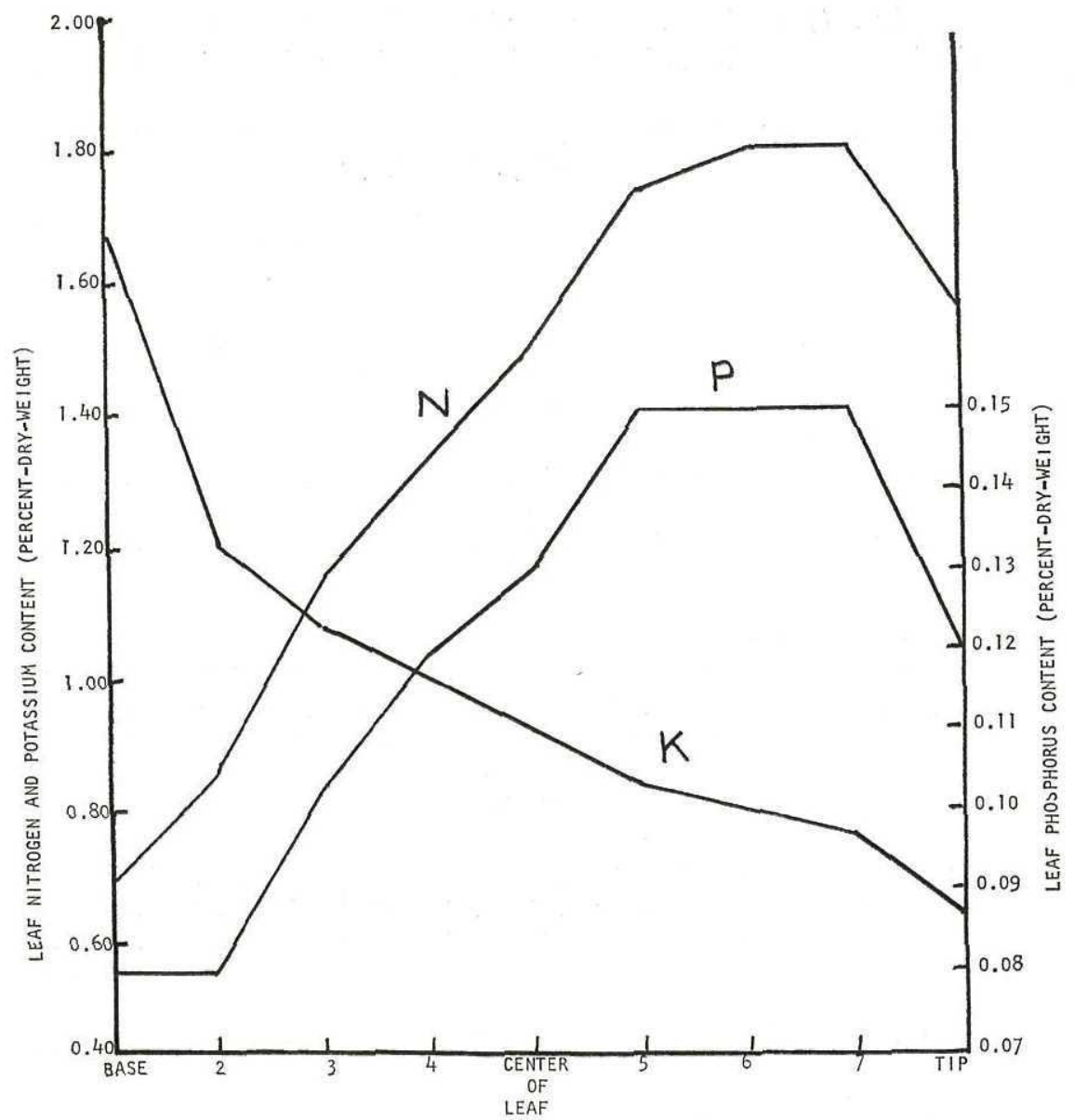

Fig. 1.-Distribution of nitrogen, phosphorus, and potassium in 6-inch leaf sections of P.R. 980, including midrib.

If the sugarcane leaf were rather uniform in its nutrient composition along its long axis, there would be no particular concern about a little variation as to what part of the leaf is used. However, this is not so, for there are quite large variations in nutrient composition for various sections of the leaf, as shown in figure 1 and table 3. Nitrogen increases almost linearly and 
at a rapid rate moving from base to leaf tip. Phosphorus behaves in a similar manner, although the rate of increase is not quite so rapid. The reverse is true for potassium; leaf values decrease quite rapidly from base to tip. A few inches either side of the leaf center can cause a considerable variation in nutrient content, especially of nitrogen and potassium. Farquhar and Lee (1) obtained similar trends for nitrogen and potassium using 8-inch leaf sections of Pindar in Queensland. Tk eir trend for phosphorus was

TABLE 3.-The distribution of nutrient elements in the various portions of the sugarcane leaf blade, P.R. 980

\begin{tabular}{|c|c|c|c|c|c|c|c|c|c|}
\hline \multirow[b]{2}{*}{ Element determined } & \multicolumn{9}{|c|}{$\begin{array}{l}\text { Distribution of mineral elements in the leaf blade on a percent-dry-weight } \\
\text { basis for 6-inch leaf sections ranging from base to tip of leaf }\end{array}$} \\
\hline & $\begin{array}{c}\text { Nearest } \\
\text { to base } \\
1\end{array}$ & 2 & 3 & 4 & ${ }_{5}^{\text {Center }}$ & 6 & 7 & 8 & $\begin{array}{l}\text { Nearest } \\
\text { to tip } \\
9\end{array}$ \\
\hline
\end{tabular}

Whole Leaf

\begin{tabular}{l|r|r|r|r|r|r|r|r|r}
\hline Nitrogen & 0.69 & 0.86 & 1.15 & 1.33 & 1.50 & 1.73 & 1.80 & 1.79 & 1.55 \\
Phosphorus & .08 & .08 & .10 & .12 & .13 & .15 & .15 & .15 & .12 \\
Potassium & 1.69 & 1.21 & 1.08 & 1.01 & .93 & .84 & .80 & .77 & .64 \\
\hline
\end{tabular}

Lamina

\begin{tabular}{l|r|r|r|r|r|r|r|r|r}
\hline $\begin{array}{l}\text { Nitrogen } \\
\text { Phosphorus }\end{array}$ & 1.16 & 1.24 & 1.57 & 1.71 & 1.87 & 1.90 & 2.01 & 2.00 & 1.95 \\
Potassium & 1.76 & .13 & .14 & .15 & .16 & .16 & .16 & .16 & .14 \\
.86 & 1.23 & 1.15 & 1.07 & 1.01 & .91 & .86 & .72 \\
\hline & Midrib \\
\hline $\begin{array}{l}\text { Nitrogen } \\
\text { Phosphorus }\end{array}$ & 0.43 & 0.44 & 0.50 & 0.55 & 0.61 & 0.67 & 0.87 & 1.19 & 1.52 \\
Potassium & 2.06 & .06 & .06 & .06 & .07 & .07 & .09 & .10 & .14 \\
.83 & 1.44 & 1.30 & 1.25 & 1.02 & .92 & .86 & .83 & .73 \\
\hline
\end{tabular}

not definite. They also showed that calcium and magnesium increased from base to tip of the leaf.

To insure accuracy in foliar-diagnostic work it is necessary that the leaf sample be taken from the same portion of the leaf each time. The use of visual estimations of the leaf center is insufficiently accurate to insure consistent and uniform sampling. Simply folding the leaf in half is a rapid means of finding the center of the long axis. A ruler or mark on the cutting table or board will ensure that the same length of section is taken from the leaf each time for analyses. If a leaf-punch or disk is used, the same care is needed in locating the leaf-punches each time, because of variation along the leaf. In fact, Farquhar and Lee (1) also found a nutrient gradi- 
ent in the lamina of the leaf from outer edge to midrib, especially for potassium where it increased 25 to 30 percent.

\section{SUMMARY}

The leaf sample is a vital and critical factor in a sugarcane foliar-diagnosis program. For, no matter how accurate the chemical analyses, an accurate diagnosis of the sugarcane's fertilizer status is impossible if leaf samples are taken improperly.

Variations were found in the nutrient content of the various leaves of the sugarcane plant, as well as variation within the leaf itself. Some of the variations encountered were:

1. The nitrogen and phosphorus contents of the leaf blade were higher than those of the leaf sheath; the reverse was true for potassium.

2. The nitrogen content of the leaf showed only a slight tendency to increase with increasing leaf number. Phosphorus, potassium, and sheath moisture dropped rapidly with increasing leaf number.

3. When the midrib of the leaf blade was eliminated, there was an increase in leaf-blade nitrogen and phosphorus, and a decrease in potassium content.

4. There was considerable variation in the nutrient content of the leaf as we moved from its base to tip. Nitrogen and phosphorus content increased rapidly from base to tip; the reverse was true for potassium.

\section{RESUMEN}

La muestra de la hoja es factor de vital importancia en un programa para el diagnóstico foliar de la caña de azúcar. No importa la exactitud con que se haga el análisis químico, no es posible hacer un diagnóstico correcto de los requerimientos de abono de la caña si las muestras no se toman debidamente.

Se encontraron variaciones tanto en el contenido de nutrimentos en las distintas hojas, como en la hoja misma. Algunas de estas variaciones fueron:

1. El contenido de nitrógeno y fósforo fue mayor en la lámina de la hoja que en la yagua; con el potasio sucedió lo contrario.

2. El contenido de nitrógeno de la hoja sólo reveló una ligera tendencia a aumentar según ascendió el orden númerico de la hoja. La humedad y el contenido de fósforo y potasio en la yagua disminuyeron rápidamente según ascendió el orden númerico de la hoja.

3. Cuando se eliminó la vena central de la lámina de la hoja, aumentó el contenido de nitrógeno y fósforo y disminuyó el de potasio.

4. Hubo una variación considerable en el contenido de nitrógeno de la hoja, según se ascendió de la base hacia la punta. EI contenido de nitrógeno y fósforo aumentó rápidamente de la base hacia la punta; con el potasio sucedió lo contrario. 


\section{LITERATURE CITED}

1. Farquhar, R. H., and Lee, J. B., Variability associated with sugarcane leaf sampling for foliar diagnosis, Proc. Int. Soc. Sugarcane Technologists, XI Congress, Mauritius, pp. 203-14, 1962.

2. Halais, P., Foliar diagnosis, a new guide to fertilization of sugarcane in Mauritius, Proc. Int. Soc. Sugarcane Technologists, VII Congress, Brisbane, pp. 218-32, 1950.

3. Riera, A., Modificación en los análisis químicos de la hoja de la caña de azúcar, Rev. Co. de Quimicos de P.R. 21 (1): 12-4, June 1963.

4. Samuels, G., The relative merits of various methods of foliar diagnosis for sugarcane, Proc. Inter. Soc. Sugarcane Technologists, X Congress Hawaii, pp. 529-37, 1959.

5. Samuels, G., Landrau, P., Alers, S., and A. Riera, The Method of Foliar Diagnosis as Applied to Sugarcane, Univ. P.R., Agr. Exp. Sta. Bull. 123, Feb., 1955.

6. Van Dillewijn, C., Botany of Sugarcane, pp. 103-4, The Chronic Botanica Co., Waltham, Mass. 1952. 